\title{
PUISI BERHUMOR: STRATEGI TUTUR REMY SYLADO ${ }^{1}$
}

\author{
(Humour in Poetry: Remy Silado's Speech Strategy)
}

\author{
Basori \\ Balai Bahasa Kalimantan Tengah \\ Jalan Tingang Km 3,5, Palangka Raya, Kalimantan Tengah, Indonesia \\ Pos-el: tjakbasori@gmail.com
}

\begin{abstract}
Abstrak: Puisi sebagaimana karya sastra yang lain merupakan sebuah tuturan. Jika puisi adalah sebuah tuturan, hal itu mengindikasikan adanya penutur dan mitra tutur. Dalam penelitian ini puisi sebagai tuturan dikaji menggunakan teori-teori pragmatik yang mencakupi implikatur, permainan bahasa, serta implikasinya terhadap pemaknaan pembaca sebagai mitra tutur. Penelitian ini akan mendeskripsikan strategi tutur Remy Sylado dan kemahirannya dalam memanfaatkan unsur-unsur bahasa dalam penciptaan puisi sehingga memiliki dampak humor bagi pembacanya. Teori yang digunakan untuk membedah data adalah teori-teori pragmatik yang berkaitan dengan implikatur, prinsip kerja sama, dan prinsip kesantunan. Penggunaan prinsip kerja sama dan prinsip kesantunan berkaitan dengan analisis bahwa puisi-puisi ini dapat dimasukkan dalam kategori humor. Secara umum humor diidentifikasikan sebagai gejala yang menyalahi bahasa. Prinsip ketidaksejajaran, ketakterdugaan, dan asosiasi pornografi merupakan ciri-ciri umum humor. Telitian ini menghasilkan empat strategi yang digunakan oleh Remy Sylado untuk menyampaikan ide-idenya kepada pembaca. Strategi-strategi tersebut adalah permainan kata, asosiasi pornografi, salah ucap, dan ketakterdugaan.
\end{abstract}

Kata Kunci: puisi, humor, strategi tutur, Remy Sylado

\begin{abstract}
Poetry, as well as other literary works, is a speech. If poetry is a speech, it indicates the presence speaker and hearer. In this study, a poetry as speech is examined using pragmatic theories which include implicatures, language play, as well as the implications of the meaning to the reader as a hearer. This study will describe the Remy Sylado strategy and skill in the use of language elements in the creation of poetry that has the effect of humour for readers. The theory is used to dissect the data is pragmatic theory relating to implicature, cooperative principle, and politeness principle. The use of cooperative and politeness principle concerned with the analysis that these poems can be included in the category of humour. In general, humour was identified as a symptom that violates the language. The principle of inequality, unpredictability, and pornography is a humour characteristic. This carefully situations produced four strategies used by Remy Sylado to convey his ideas to the reader, namely puns, pornography, slip of the tongue, and unpredictability.
\end{abstract}

Keywords: poetry, humour, strategy, Remy Sylado

1 (Konsep awal artikel ini pernah disampaikan dalam Seminar Internasional Bahasa dan Sastra 2014, Kantor Bahasa Provinsi Nusa Tenggara Barat. Naskah diperbaiki untuk keperluan pemuatan di Jurnal Ilmiah) 


\section{PENDAHULUAN}

Puisi sebagaimana karya sastra yang lain merupakan sebuah tuturan. Jika puisi adalah sebuah tuturan, hal itu mengindikasikan adanya penutur dan mitra tutur. Penutur tentu saja adalah penyair yang menyusun pesan-pesan dalam puisi yang dikomunikasikannya kepada pembaca sebagai mitra tuturnya. Dalam hal ini penyair atau penutur dapat mewakilkan tuturannya melalui tokoh-tokoh atau deiksis yang digunakannya dalam tuturan.

Tidak banyak peneliti yang mencoba membedah puisi dari cara strategi tutur penyairnya atau bahkan humor. Selama ini puisi selalu didekati atau dikaji melalui simbol-simbol yang berkaitan dengan bagaimana pembaca mesti memahami makna puisi. Di antara yang sedikit itu terdapat Lamusu (2010) yang mengambil objek puisi Rendra dan Taufik Ismail. Ia berusaha membandingkan pemarkah kohesi yang dipakai keduanya untuk mencari karakteristik kedua penyair tersebut. Telitian ini hanya menghasilkan pembandingan karakteristik antara dua penyair tersebut. Lamusu tidak mendalami bagaimana penyair menggunakan strategi tertentu untuk menyampaikan ide-ide tertentu pada pembacanya. Ada pula Basori (2011) yang meneliti puisi-puisi Taufik Ismail dari sisi implikasi pragmatis ironi yang digunakan oleh penyair. Penelitian ini menghasilkan simpulan adanya dua fungsi ironi dalam puisi Taufik Ismail. Dua fungsi tersebut adalah sarana untuk menciptakan metafora dan untuk menegaskan nada menyindir atau mencemooh, yang kadangkadang sampai pada taraf sarkasme. Paradoks-paradoks yang digunakan memunculkan suasana ironis. Sementara, pemakaian hiperbol mempertegas metafora dan menghidupkan imaji visual secara lebih kuat. Pemakaian hiperbol yang menimbulkan efek sindiran atau mencemooh lebih menonjolkan ciri ironinya.
Puisi-puisi Remy Sylado selama ini hanya dikaji dan didekati menggunakan teori-teori sastra, semiotika, dan stilistika. Dua di antaranya adalah penelitian Mabruri (2013) dan Muttaqin (2016). Mabruri (2013) mengambil sepuluh puisi dari kumpulan puisi Kerygma \& Martyria. Penelitian ini mendeskripsikan struktur puisi dan potret sosial sepuluh sajak Remy Sylado dan relevansinya dengan pembelajaran sastra di SMA. Potret sosial dideskripsikan menggunakan teori semiotika Pierce. Sementara itu, penelitian Muttaqin (2016) mendeskripsikan penggunaan bahasa yang unik yang khas Remy Sylado. Keunikan penggunaan kata tersebut yang kemudian membuat Remy digelasi sebagai penyair mbeling. Muttaqin (2016) menggunakan teori-teori stilistika (gaya bahasa).

Di samping itu terdapat peneliti lain yang menggunakan teori-teori pragmatik dan humor. Penelitian-penelitian tersebut umumnya tidak mengambil teks puisi sebagai data penelitian. Di antaranya adalah penelitian Yuniarsih (2011), Faridl (2012) dan Yunitawati (2013). Yuniarsih (2011) mengungkap unsur humor dalam buku ibtasim karya Aid Alqarni, Faridl (2012) mendeskripsikan implikatur-implikatur percakapan dalam wacana humor Gus Dur, dan Yunitawati (2013) mendeskripsikan penyimpangan prinsip kerja sama dan prinsip kesopanan dalam kartun karya Muhammad Mice Misrad. Tiga penelitian ini menjadi acuan dalam menentukan ciri humor dalam sebuah wacana. Penelitianpenelitian yang membahas tentang humor dan ciri-cirinya ini sangat mendukung dan membantu dalam upaya menyingkap strategi tutur Remy Sylado dalam penelitian ini.

Hal inilah yang menjadi dasar penulis melakukan penelitian terhadap puisi-puisi Remy Sylado dengan menggunakan teori pragmatik dan teori humor. Penulis ingin memanfaatkan teori pragmatik dan humor untuk menangkap makna yang disampaikan penyair. Sebagaimana yang dinyatakan di 
awal bahwa bagaimanapun puisi adalah tuturan. Dengan memperhatikan bentukbentuk tuturan dalam puisi pembaca diharapkan menemukan bentuk-bentuk makna yang disampaikan penyair.

Menurut Kridalaksana (2001) gaya bahasa (style) mempunyai tiga pengertian, yaitu pemanfaatan atas kekayaan bahasa oleh seseorang dalam bertutur atau menulis, pemakaian ragam tertentu untuk memperoleh efek-efek tertentu, dan keseluruhan ciri-ciri bahasa sekelompok penulis sastra. Zaimar dan Harahap (2015) mengemukakan bahwa pemakaian gaya bahasa yang tepat dapat menarik perhatian penerima. Sebaliknya, jika penggunaannya tidak tepat, gaya bahasa tersebut akan sia-sia, bahkan mengganggu penerima/pembaca. Dalam sebuah tindakan komunikasi (dalam hal ini, puisi) seorang penutur merealisasikan ide dan pendapatnya melalui sebuah wacana. Tindakan komunikatif yang diwujudkan dapat menghasilkan beberapa atau bahkan banyak tuturan yang menjadi satu kesatuan wacana. Tentu dalam peristiwa tutur tersebut ada stimulus-respons dari penutur dan mitra tutur. Demikian pula, dalam wacana humor. Penutur dalam hal ini mengungkapkan idenya dalam sebuah strategi tertentu yang kemudian direspons oleh mitra tutur yang biasanya berupa tawa.

Dalam wacana humor banyak ditemukan pelanggaran prinsip kesantunan atau percakapan yang dimaksudkan untuk menciptakan tuturan humor. Menurut Grice (1975) prinsip kesantunan adalah prinsip yang berkenaan dengan aturan tentang hal-hal yang bersifat sosial, estetika, dan moral dalam bertindak tutur. Prinsip kesantunan dibutuhkan untuk melengkapi prinsip kerja sama dan mengatasi kesulitan yang timbul akibat penerapan prinsip kerja sama. Prinsip kesantunan juga bertujuan untuk menjaga dan memelihara hubungan sosial antara pelaku tutur, yakni dengan menggunakan bahasa yang sopan dan santun pada saat mengujarkan sebuah tuturan. Wacana humor merupakan stimulus yang memberikan respons atau efek kepada mitra tuturnya. Respons atau efek yang ditimbulkan oleh wacana humor bisa berupa tertawa, tersenyum, meringis, ataupun menangis. Begitu pula dalam wacana puisi-puisi Remy Sylado Puisi Mbeling. Dalam kumpulan puisi ini, Remy Sylado banyak menggunakan strategistrategi khusus untuk mengungkapkan maksud dan tujuan penciptaannya dalam bentuk puisi-puisi "humor". Remy Sylado tentu saja tidak berharap puisi-puisinya monoton dan takmampu menarik perhatian pembaca. Ia tidak hanya menyampaikan ide dan gagasan. Ia berusaha menghibur dan untuk itu ia memerlukan strategi-strategi khusus agar maksud dari puisi-puisinya tersebut dapat ditangkap dengan baik oleh pembaca.

Menghadapi gaya tutur yang berbeda sebagaimana yang digunakan oleh Remy Sylado, pembaca perlu membekali diri dengan terori-teori yang berkaitan dengan humor dan pragmatik untuk menangkap makna dan pesan yang disampaikan dalam puisi-puisi tersebut.

Teori yang digunakan untuk menjelaskan data dalam penelitian ini adalah teori pragmatik dan teori humor. Teori-teori pragmatik yang digunakan adalah yang berkaitan dengan prinsip kerja sama dan prinsip kesantunan Leech (1983). Teori Leech ini diterangjelaskan oleh Wijana (2003); Wijana dan Rohmadi (2009); Nadar (2013); Kurniati (2010); dan Basori (2011) dengan objek kajian yang berbeda-beda. Wijana (2003) menggunakan teori ini untuk membedah kartun. Wijana dan Rohmadi (2009) dan Nadar (2013) membahas teori ini dan menjelaskan bagaimana cara menggunakannya sebagai pisau analisis sebuah penelitian. Kurniati (2010) menggunakan prinsip kerja sama dan kesantunan Leech ini sebagai pisau bedah untuk menganalisis wacana humor berbahasa Sunda. Sementara itu, Basori (2011) memanfaatkannya untuk memahami dan mencerap makna puisi-puisi Taufik Ismail dalam kaitannya dengan penggunaan ironi. Untuk melengkapi teori pragmatik 
tersebut, penulis juga menggunakan teori humor Raskin (1985) dan Crystal (1998). Teori humor tersebut juga digunakan oleh Wijana (2003b), dan Kurniati (2010) dalam penelitiannya. Para peneliti ini menggunakan teori-teori pragmatik sebagai alat untuk mengidentifikasi adanya humor dalam sebuah wacana.

Dengan menempatkan puisi sebagai tuturan, penulis mengkaji gejala-gejala kebahasaan yang dipakai oleh Remy Sylado dalam puisi-puisinya (Sylado, 2004) untuk kemudian menjelaskan adanya strategi tutur tertentu yang menjadi gaya khas Remy Sylado. Asumsi dasarnya adalah bahwa setiap penyair pasti memiliki strategi tutur (gaya) yang berbeda dengan penyair lainnya.

Prinsip kerja sama dan prinsip kesantunan digunakan sebagai parameter untuk menentukan sebuah data (puisi) masuk dalam kategori humor atau bukan. Pelanggaran-pelanggaran terhadap prinsip kerja sama dan prinsip kesantunan merupakan salah satu wujud humor. Pelanggaran-pelanggaran prinsip pragmatik tersebut merupakan salah satu bentuk manipulasi linguistik untuk menarik kelucuan dalam sebuah humor.

Pelanggaran-pelanggaran terhadap prinsip pragmatik merupakan salah satu strategi yang digunakan oleh Remy Sylado dalam menulis puisinya. Hal itulah yang kemudian memunculkan efek humor dalam puisi-puisi Remy Sylado.

\section{METODE PENELITIAN}

Penelitian ini merupakan penelitian lintas disiplin yang berusaha untuk mengupas bahasa secara interpretatif untuk menemukan pemahaman tentang kebudayaan. Oleh karena itu, pendekatan yang digunakan bersifat eklektik dengan tetap mempertahankan kekhasannya dalam pemilihan data kebahasaan sebagai objek studi (parole). Ancangan penelitian yang digunakan bersifat ideografis dan kecenderungan penerapan metodologi kualitatif pendekatan fenomenologis.

Berdasarkan pada konsep tersebut, karya yang dikaji dianalisis secara tekstual tanpa mengaitkan dengan hal-hal di luar teks. Pikiran-pikiran penyair yang melatari kelahiran puisi dijadikan sebagai kerangka acuan penafsiran sebagai wujud teori yang khas. Dalam analisis, teks puisi disajikan secara utuh. Selanjutnya diamati ciri tuturan, tipologi tuturan, serta makna yang tersirat di dalamnya. Langkah berikutnya adalah mengklasifikasi data berdasarkan ciri dan tipologi tutur yang digunakan. Ciri dan tipologi tuturan ini diklasifikasi berdasarkan teori pragmatik yang sudah disiapkan. Teori pragmatik yang digunakan dalam penelitian ini lebih spesifik pada pelanggaran-pelanggaran terhadap prinsipprinsip pragmatik (prinsip kerja sama dan prinsip kesantunan). Pelanggaranpelanggaran terhadap prinsip pragmatik ini kemudian dipakai untuk mengidentifikasi adanya strategi tertentu yang digunakan Remy Sylado yang sekaligus membedakannya dengan penyair-penyair yang lain

\section{PEMBAHASAN}

Wacana humor secara kultural biasanya disampaikan dengan bentuk bahasa tertentu, yaitu bahasa di luar struktur formal atau bahasa ragam informal. Bahasa ragam informal dianggap lebih tepat dan luwes untuk mengekspresikan aspek humor. Hal ini dapat dipahami karena bahasa informal cenderung lebih luwes, tidak terikat pada konvensi dan kaidah bahasa baku.

Dalam sebuah pertuturan, penutur dan mitra tutur sama-sama menyadari bahwa ada kaidah-kaidah yang mengatur tindakannya, penggunaan bahasanya, dan interpretasi-interpretasinya terhadap tindakan dan tuturan mitra tuturnya. Setiap peserta pertuturan bertanggung jawab terhadap tindakan pematuhan dan pelanggaran terhadap kaidah kebahasaan dalam interaksi lingual tersebut. 
Dalam komunikasi yang wajar agaknya dapat diasumsikan bahwa seorang penutur mengartikulasikan tuturan dengan maksud untuk mengomunikasikan sesuatu kepada mitra tuturnya dengan harapan mitra tuturnya dapat memahami pesan yang disampaikannya. Untuk mencapai harapan tersebut penutur akan selalu berusaha menyampaikan tuturan yang sesuai dengan konteksnya, jelas dan mudah dipahami maksudnya, padat dan ringkas kemasannya, dan selalu pada persoalan sehingga tidak menghabiskan waktu mitra tuturnya.

Hal ini berbeda dengan yang terjadi pada wacana jenis humor. Di dalam humor, penyimpangan-penyimpangan yang dilakukan terhadap berbagai aturan tersebut dimaksudkan sebagai landasan untuk memperoleh efek lucu. Inilah perbedaan esensial antara wacana humor dan wacana nonhumor. Wacana nonhumor selalu mematuhi secara ketat kaidah-kaidah pragmatik sebagaimana yang terpapar dalam berbagai maksim dan parameter pragmatik, sementara wacana humor justru menyimpangkan kaidah-kaidah tersebut. Bahasa humor secara pragmatik atau informatif jauh menyimpang dari pemakaiannya yang wajar walaupun diekspresikan dengan bahasa percakapan sehari-hari.

Wacana humor pada dasarnya menyangkut pemaduan dua makna, persepsi, dan konsepsi yang berbeda. Dalam upaya pencapaian efek lucu tersebut, dua makna, persepsi, dan konsepsi itu secara kreatif dipermainkan oleh para pencipta humor sehingga memunculkan ketakterdugaan dan keanehan yang memang merupakan syarat humor itu sendiri.

Berkaitan dengan penggunaan bahasa dalam puisi-puisi Remy Sylado, setidaknya ada empat strategi tutur yang dipakai oleh Remy Sylado dalam puisi-puisinya. Empat strategi tersebut adalah permainan kata, asosiasi pornografi, gejala salah ucap, dan ketakterdugaan.

\section{Permainan Kata}

Remy Sylado dalam hal ini sangat mahir dalam memainkan kata. Permainan kata itu dapat terjadi dalam kerangka fonologis, morfologis, atau pemanfaatannya dalam struktur sintaktis. Puisi-puisi berikut menunjukkan hal itu.

Fonem, sebagai unsur esensial bahasa memiliki peran yang bersifat sistematik dan struktural. Peranannya yang bersifat sistemik mengakibatkan bunyi-bunyi itu bersifat distingtif di dalam susunan berlajur. Sementara itu, peranannya yang bersifat struktural mengakibatkannya bersifat distingtif dalam susunan beruntun. Pagi dan bagi memiliki makna yang berbeda karena peranan /p/ dan /b/ sebagai hubungan paradigmatik. Kata alir, liar, lari memiliki makna yang berbeda karena kedistingtifan bunyi-bunyinya yang sintagmatik.

Sifat-sifat fonem yang demikian yang kemudian dimanfaatkan oleh Remy Sylado untuk mengkreasi karya-karya puisisinya. Remy Sylado terkesan sangat pandai memain-mainkan kata yang memiliki kemiripan dalam kaitannya dengan hubungan sintagmatik dan paradigmatik tersebut. Perhatikan puisi-puisi berikut.

(1)

yang menulis warta

= wartawan

yang menulis puisi

= puisiwan

yang menulis prosa

= prosawan

yang menulis drama

= dramawan

yang belum ditulisi

= perawan

(Akhiran Wan)

Puisi yang berjudul "Akhiran Wan" tersebut menunjukkan kelihaiannya dalam memainkan morfem \{wan\}. Morfem tersebut merupakan akhiran pembentuk nomina yang memberi makna ahli dalam 
bidang, orang yang bergerak dalam, dan orang yang memiliki sifat. Empat bentuk pertama dalam puisi tersebut, wartawan, puisiwan, prosawan, dan dramawan, merupakan bentuk turunan yang berasal dari bentuk dasar+akhiran $\{$ wan $\}$. Bentuk terakhir, perawan, bukanlah bentuk turunan sebagaimana empat bentuk sebelumnya. Di sinilah kreativitas penyair terlihat. Penggunaan bentuk ini menimbulkan efek kejut pada pembaca. Strategi kejutan seperti ini merupakan salah satu bentuk pelanggaran terhadap prinsip kerja sama. Pada titik inilah ke-mbeling-an penyair terasa. Kaitannya dengan rangkaian kata sebelumnya juga menunjukkan hal itu. Remy secara cerdas menggunakan menulis sebagai penanda. Perawan bukanlah yang menulis pera, melainkan yang belum ditulisi.

Salah satu ciri humor sebagaimana diungkapkan oleh Raskin (1985), Crystal (1998), Wijana (2003a), dan Kurniati (2010) adalah permainan kata. Ciri ini ditemukan dalam humor berbagai bahasa. Selain itu humor juga berkaitan dengan teori ketidaksejajaran. Teori ketidaksejajaran mengemukakan bahwa humor secara tidak kongruen menyatukan dua makna atau penafsiran yang berbeda ke dalam suatu objek yang kompleks. Ketidaksejajaran dan ketidaksesuaian bagian-bagian itu dipersepsikan secara tibatiba oleh penikmatnya. Sesuatu yang tidak sejajar menurut paham ketidaksejajaran oleh penganut paham pertentangan dipandang sebagai fenomena yang bertentangan. Pertentangan tersebut, misalnya antara sesuatu yang sama dan yang tidak sama, juga pertentangan antara sesuatu yang nyata dan tidak nyata. Konsep pertentangan yang lain, seperti pertentangan antara persahabatan dan permusuhan, antara permainan dan keseriusan, serta antara perasaan gembira dan tertekan.

Ketidaksejajaran dan ketidaksesuaian bait lima dengan empat bait sebelumnya menimbulkan efek kejut yang menggiring pembaca pada penafsiran berbeda dalam objek yang kompleks. Setelah empat bait pembaca disuguhi sesuatu yang wajar, bait terakhir langsung memberi kejutan dengan situasi yang berbeda. Empat bait awal menggunakan kalimat aktif, sementara bait kelima menggunakan kalimat pasif. Strategi kejut ini merupakan salah satu ciri wacana humor sebagaimana yang dikemukakan oleh Raskin (1985).

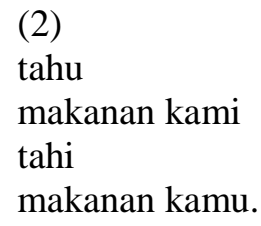

Pada data (2), Remy Sylado menggunakan pasangan minimal, tahu dan tahi, sebagai alat untuk menciptakan kesan humor.

Bahasa Indonesia memiliki banyak sekali pasangan minimal. Ini dimanfaatkan oleh Remy Sylado sebagai salah satu cara mengungkapkan humor dalam puisipuisinya.

Penggunaan tahi yang dilanjutkan dengan makanan kamu merupakan bentuk pelanggaran terhadap prinsip kesopanan. Pelanggaran inilah yang kemudian memunculkan efek humor dalam puisi ini.

Penjajaran pasangan minimal kami dan kamu, tahi dan tahu menunjukkan gejala mempermainkan kata yang memiliki hubungan paradigmatik. Perbedaan makna disebabkan penggunaan fonem /i/ dan /u/. Puisi ini sekaligus merupakan bentuk pelanggaran terhadap prinsip-prinsip pragmatik, khususnya prinsip kerja sama, yang sekali lagi berimplikasi terhadap terciptanya efek humor.

Dalam sebuah pertuturan, penutur dan mitra tutur sama-sama menyadari bahwa ada kaidah-kaidah yang mengatur tindakan, penggunaan bahasa, dan interpretasiinterpretasi terhadap tindakan dan tuturan mitra tuturnya. Setiap peserta pertuturan bertanggung jawab terhadap tindakan pematuhan dan pelanggaran terhadap 
kaidah kebahasaan dalam interaksi lingual tersebut.

Strategi permainan kata juga digunakan oleh Remy Sylado dalam bentuk yang lain. Pada puisi "Kera dan Beruk", ia mengeksploitasi penyusunan akronim. Ini merupakan salah satu bentuk kreativitas dalam berakronim.

(3)

orang tua mengatai
"kera"
kenakalan remaja
orang muda mengatai
"beruk"
babe emak kemaruk
(Kera dan Beruk)

(Kera dan Beruk)

Jika kera adalah kenakalan remaja, beruk adalah babe emak kemaruk. Mengapa yang dipakai babe dan emak? Leksem itulah yang pas untuk menjadi akronim beruk. Ini tentu saja berkaitan langsung dengan akronim yang digunakannya sebelumnya, kera. Kera dan beruk merupakan binatang sejenis, sama-sama jenis primata. Pemilihan babe dan emak tentu saja untuk menyesuaikan dengan akronim yang digunakan sebelumnya. Remy tentu tidak memilih kata-kata lain yang semakna dengan itu, misalnya ayah, $i b u$, papi, mami, bapak, apalagi abi atau umi karena tentu saja tidak akan menciptakan akronim beruk tadi.

Puisi berikut ini bermain-main dengan bentuk ulang dalam bahasa Indonesia. Beberapa kata dalam bahasa Indonesia diketahui memiliki makna yang berbeda dengan bentuk dasarnya.

(4)

Langit

tidak berbatas

Langit-langit

bagian pembatas

Otak

untuk pikiran

Otak-otak

untuk santapan
Kuda

kakinya kekar

Kuda-kuda

kaki pendekar

Suka

lahirkan cinta

Suka-suka

lahirkan duka derita

Hati

rasam perasaan

Hati-hati

rasam kewaspadaan.

(Di Langit Otak Kuda Suka Hati)

Puisi ini bermain-main dengan bentuk ulang. Langit, otak, kuda, suka, dan hati jika diulang akan menghadirkan makna yang berbeda dengan bentuk dasarnya. Perbedaan makna itu ada yang benar-benar berbeda, seperti kuda dan kuda-kuda serta otak dan otak-otak, ada pula yang maknanya masih berhubungan dengan makna dasarnya, seperti suka dan sukasuka, hati dan hati-hati.

\section{Asosiasi Pornografi}

Strategi kedua yang digunakan oleh Remy Sylado adalah asosiasi pornografi. Asosiasi pornografi dalam wacana humor berfungsi untuk menarik perhatian pembaca atau pendengar. Hal ini disebabkan agar wacana tersebut diminati untuk dibaca. Daya tarik yang dapat memunculkan asosiasi pornografi tersebut dapat berupa ungkapanungkapan, kata-kata, idiom-idiom, atau tema-tema dalam wacana humor yang dipilih oleh para penulis. Dengan adanya asosiasi pornografi tersebut, pembaca seakan-akan terhipnosis untuk menikmatinya.

Asosiasi pornografi dalam wacana humor berfungsi pula untuk menghibur pembaca. Pembaca biasanya akan terhibur apabila membaca wacana yang berasosiasi pornografi. Wacana humor yang berasosiasi pornografi dapat menghilangkan rasa suntuk, stres, atau pun kesal. Untuk itu, adanya asosiasi pornografi dalam wacana 
humor tersebut dapat dijadikan sebagai hiburan "murah" yang dapat merenggangkan saraf-saraf dan otot-otot yang tegang. Fungsi menghibur ini dapat dimunculkan dari ungkapan-ungkapan, kata-kata, teknik penciptaan, atau pun tematema yang lucu, tetapi berasosiasi pornografi. Hal ini dapat dilihat pada data berikut.

(5)

Mei Hwa perawan 16 tahun

Farouk perjaka 16 tahun

Mei Hwa masuk kamar jam 24.00

Farouk masuk kamar jam 24.00

Mei Hwa buka blouse

Farouk buka hemd

Mei Hwa buka rok

Farouk buka celana

Mei Hwa buka BH

Farouk buka singlet

Mei Hwa buka celana dalam

Farouk buka celana dalam

Mei Hwa telanjang bulat

Farouk telanjang bulat

Mei Hwa pakai daster

Farouk pakai kamerjas

Mei Hwa naik ranjang

Farouk naik ranjang

Lantas mereka tidurlah

Mei Hwa di taipeh

Farouk di Kairo.

(Kesetiakawanan Asia-Afrika)

Asosiasi pornografi dalam wacana puisi di atas berfungsi untuk membuat penasaran pembaca. Pembaca biasanya akan penasaran dengan adanya asosiasi pornografi dalam wacana humor. Pemunculan rasa penasaran tersebut dapat disebabkan oleh pemanfaatan teknik metafora. Dalam wacana humor, teknik metafora digunakan untuk menciptakan asosiasi "yang bukan-bukan" yang dapat memunculkan rasa penasaran dalam benak para pembaca. Pada puisi "Kesetiakawanan Asia Afrika" pembaca diajak untuk menikmati puisi dalam imaji pornografis melalui dua tokoh yang ditampilkan, Mei Hwa dan Farouk. Di akhir puisi pembaca yang sudah terbawa pada asosiasi pornografis dikejutkan dengan situasi yang berbeda. Situasi ini merupakan bentuk kejutan, kecohan. Asosiasi pornografi dalam wacana humor berfungsi pula untuk pengecoh pembaca. Mengecoh di sini tidak berarti merusak pikiran pembaca, tetapi lebih ditekankan pada usaha penyesatan pikiran sehingga akan menimbulkan daya tarik tersendiri dalam benak pembaca. Pengecohan pikiran pembaca tersebut dilakukan dengan teknik makna ganda atau ambiguitas. Asosiasi pornografi dalam wacana humor yang berfungsi pengecoh ini dapat menjadikan daya tarik tersendiri bagi pembaca.

Puisi berikutnya yang menggunakan asosiasi pornografi antara lain "TelorTelor", "Jawa dan Melayu", "Penistaan Terhadap Ibu", dan "Karmina Pengantin Baru”.

(6)

dua telor

martabak spesial

tiga telor

martabak istimewa

empat telor

sepasang homoseks

(Telor-Telor)

(7)

Aku

tahu betul

bahwa panggilan

anak laki di Jawa: tole

berasal dari bahasa Jawa: kontole

Yang

aku tak tahu

dari mana asalnya

bahasa Melayu: tempik sorak.

(Jawa dan Melayu)

(8)

nila

setitik

merusak

susu sepayudara.

(Penistaan Terhadap Ibu) 
(9)

Sudah gaharu cendana pula

Buka bajumu celana pula.

\section{(Karmina Pengantin Baru)}

Penjajaran empat telor dan homoseks (6), kontole dan tempik sorak (7), sepayudara (8), dan buka bajumu celana pula (9) secara pragmatis membawa pembaca pada asosiasi pornografis. Istilahistilah yang berkonotasi seks (asosiasi pornografis) memiliki implikasi humor yang lebih kuat dibandingkan humor jenis lain. Hal itu terjadi karena humor seks dianggap dapat memberikan jalan keluar untuk melepaskan diri dari tekanan norma moral dan agama. Bahasa di dalam humor seks dapat diterima masyarakat sebagai hal biasa meskipun perilaku seksnya sebenarnya dinilai tabu.

Pengungkapan istilah-istilah seks yang berhubungan dengan kelamin bukan merupakan kelaziman dalam masyarakat Indonesia. Topik seks menjadi hal yang tabu untuk diungkapkan di depan publik. Remy Sylado memanfaatkannya sebagai salah satu cara mengungkapkan ide.

Penggunaan istilah-istilah seks dan kelamin secara terbuka merupakan salah satu bentuk pelanggaran terhadap prinsip kesopanan. Pelanggaran inilah yang memancing pembaca untuk merasakan dan menikmati unsur-unsur humor dalam puisipuisi tersebut.

\section{Ketakterdugaan}

Remy Sylado juga menggunakan strategi kejut, ketakterdugaan, dalam puisipuisinya. Ketakterdugaan ini juga merupakan salah satu ciri humor. Ketakterdugaan ini berkaitan dengan tuturan yang keluar dari konteks. Berikut ini puisi-puisi yang menggunakan strategi ketakterdugaan.

Dia

tak bicara

selama satu tahun

\author{
Dia \\ tak tertawa \\ selama satu tahun \\ Dia \\ tak makan-minum \\ selama satu tahun \\ Dia \\ telah wafat \\ satu tahun yang lalu. \\ (Selesai)
}

Ketidaksejajaran dan ketidaksesuaian bait empat dengan tiga bait sebelumnya menimbulkan efek kejut yang menggiring pembaca pada penafsiran berbeda dalam objek yang kompleks. Setelah tiga bait pembaca disuguhi sesuatu wacana yang wajar, bait terakhir langsung memberi kejutan dengan situasi yang berbeda. Tiga bait awal menggunakan klausa negatif, sementara bait keempat menggunakan klausa positif. Strategi kejut ini merupakan salah satu ciri wacana humor sebagaimana yang dikemukakan oleh Monro.

Strategi kejutan hanya dapat diwujudkan dengan pelanggaran terhadap prinsip kerja sama. Dengan melanggar prinsip kerja sama komunikasi menjadi tersendat, tidak lancar. Inilah yang kemudian menimbulkan efek humor pada pembaca. Pelanggaran-pelanggaran prinsip kerja sama yang menciptakan efek kejutan ini dilakukan Remy Sylado dalam banyak puisinya. Data (10) menunjukkan hal tersebut.

Efek kejut yang dihasilkan melalui pelanggaran prinsip kerja sama juga dapat ditemukan dalam puisi-puisi berikut.

(11)

Hitam badannya? irian

Hitam cuacanya? malam

Biru darah?

Biru gunung? bangsawan jauh 
Biru laut?

Biru film? dalam
porno
$\begin{gathered}\text { Kuning kilap? } \\ \text { mas }\end{gathered}$

Kuning butek? tai

Yang merah? darah

Yang putih?

$$
\text { pek-tay }
$$

Yang tak berwarna? kentutmu!

Data (11) mengandung pelanggaran prinsip kerja sama sekaligus prinsip kesopanan. Pelanggaran prinsip kerja sama terdapat pada bait terakhir puisi tersebut. Yang tidak berwarnall kentutmu. Penyebutan kentut yang diikuti kata ganti $\{-$ mu $\}$ merupakan bentuk pelanggaran prinsip kerja sama. Dalam komunikasi yang standar, kata ini akan sangat menyinggung mitra tutur. Pelanggaran terhadap prinsip kesopanan terdapat pada bait ketiga.

Kuning kilap?

Kuning butek?

$$
\text { tai }
$$

Penggunaan kata tai merupakan bentuk pelanggaran prinsip kesopanan.

Demikian pula dengan puisi "Belajar Menghargai Hak Asasi Kawan” berikut ini.

jika

laki mahasiswa

ya perempuan mahasiswi

jika

laki saudara

ya perempuan saudari

jika

laki pemuda

ya perempuan pemudi

jika

laki putra

ya perempuan putri jika

laki kawan

ya perempuan kawin

jika

kawan kawin

ya jangan ngintip.

(Belajar Menghargai Hak Asasi

Kawan)

Humor dapat muncul dari suatu katakata bohong dan tipuan serta muslihat. Humor dapat muncul dalam bentuk rasa simpati dan pengertian. Humor juga dapat menjadi simbol pembebasan dari ketegangan, kejenuhan, dan tekanan.

Simbol pembebasan tersebut dapat dibentuk dari pelanggaran terhadap prinsip kerja sama dan/atau prinsip kesopanan. Pelanggaran merupakan bentuk pembebasan dari kejenuhan ketika mendapati hal yang sama berturut-turut.

Data (12) menunjukkan ciri-ciri tersebut. Setelah pembaca disuguhi dengan keteraturan pada bait satu sampai bait lima, pada bait keenam dimunculkan kejutan (ketakterdugaan). Sesuatu yang tidak semestinya, yang tidak seharusnya, yang berbeda dengan bentuk-bentuk yang ada sebelumnya.

Data puisi (5), "Kesetiakawanan Asia-Afrika", juga menunjukkan ciri yang sama. Pembaca digiring untuk menikmati asosiasi pornografi pada baris-baris awal kemudian disentakkan dengan kenyataan jarak pada dua larik terakhir puisi

\section{PENUTUP}

Remy Sylado sangat pandai memanfaatkan kata dalam menyusun puisi-puisinya. Di samping memanfaatkan kata dalam sebuah permainan bahasa ia juga memanfaatkan beberapa strategi untuk menarik minat pembacanya. Strategi-strategi tersebut adalah ketakterdugaan dan asosiasi pornografi. Strategi-strategi tutur ini menempatkannya sebagai penyair yang "bebas", "nakal", "mbeling". Penyimpangan-penyimpangan yang dilakukan 
terhadap berbagai aturan kebahasaan tersebut dimaksudkan sebagai landasan untuk memperoleh efek lucu yang pada akhirnya menarik perhatian pembaca. Puisipuisi mbeling Remy Sylado pada dasarnya menyangkut pemaduan dua makna, persepsi, dan konsepsi yang berbeda. Dalam upaya pencapaian efek lucu tersebut, dua makna, persepsi, dan konsepsi itu secara kreatif dipermainkan dalam puisi sehingga memunculkan ketidakterdugaan dan keanehan yang memang merupakan syarat ke-mbeling-an.

Penelitian ini hanya sebagian kecil cara pandang pembaca dalam menghadapi, membaca, dan memaknai puisi. Ada banyak cara dan sudut pandang lain yang bisa dimanfaatkan. Setidaknya penelitian ini akan menjadi semacam "titik koma" dalam peta pembacaan puisi di Indonesia.

\section{DAFTAR PUSTAKA}

Basori. (2011). Implikatur Ironi dalam Puisi-Puisi Taufik Ismai (Tesis). Universitas Padjadjaran, Bandung.

Crystal, D. (1998). Language Play. Chicago: The University of Chicago Press.

Faridl, A. M. (2012). Implikatur-Implikatur Percakapan dalam Wacana Humor Gus Dur (Skripsi). FKIP Universitas Sebelas Maret, Surakarta.

Grice, H. P. (1975). Logic and Conversation. In Syntax and Semantics, 3, Speech Act. New York: Academic Press.

Kridalaksana, H. (2001). Kamus Linguistik. Jakarta: Gramedia Pustaka Utama.

Kurniati, A. (2010). Mekanisme Penciptaan Humor dalam Wacana Humor Sunda (Tesis). Pascasarjana Universitas Padjadjaran, Bandung.
Lamusu, S. A. (2010). Telaah Stilistika Puisi-Puisi Rendra dan Taufik Ismail. Jurnal Inovasi, 7(2).

Leech, G. (1983). Principles of Pragmatics. London: Longman.

Mabruri, Z. K. (2013). Potret Sosial dalam Sepuluh Sajak Remy Sylado dan Relevansinya dengan Pembelajaran Sastra di Sekolah Menengah Atas. Program Pascasarjana, Universitas Negeri Yogyakarta.

Muttaqin, A. (2016). Kajian Stilistika Kumpulan Puisi "Mbeling" Karya Remy Sylado (Skripsi). FKIP Universitas Nusantara PGRI Kediri, Kediri.

Nadar, F. X. (2013). Pragmatik dan Penelitian Pragmatik. Yogyakarta: Graha Ilmu.

Raskin, V. (1985). Semantic Mechanism of Humor. Dodrecht Holland: D. Reidel Publishing Company.

Sylado, R. (2004). Puisi Mbeling Remy Sylado. Jakarta: KPG.

Wijana, I. D. P. (2003a). Kartun: Studi Tentang Permainan Bahasa. Yogyakarta: Ombak.

Wijana, I. D. P. (2003b). Wacana Dagadu; Permainan Bahasa dan Ilmu Bahasa. Dalam Pidato Pengukuhan Guru Besar UGM. Yogyakarta: UGM Press.

Wijana, I. D. P., \& Rohmadi, M. (2009). Analisis Wacana Pragmatik: Kajian Teori dan Analisis. Surakarta: Yuma Pustaka.

Yuniarsih, Y. (2011). Unsur Humor dalam Buku Ibtasim Karya Aid Alqarni (Skripsi). Fakultas Ilmu Pengetahuan Budaya, Universitas Indonesia, Jakarta.

Yunitawati, A. M. (2013). Penyimpangan Prinsip Kerja Sama dan Prinsip Kesopanan Wacana Kartun pada Buku Politik Santun Dalam Kartun Karya 
Suar Bétang, Vol.12, No. 2, Edisi Desember, 2017: 197-208

\begin{abstract}
Muhammad Mice Misrad (Tesis).
Magister Pengkajian Bahasa,

Universitas Muhammadiyah Surakarta,

Surakarta.
\end{abstract}

Zaimar, O. K. S., \& Harahap, A. B. (2015).

Teori Wacana. Jakarta: Penaku. 